\title{
Retrospective survey of neoplastic disease in dogs
}

\section{Estudo retrospectivo de doenças neoplásicas em cães}

\section{Daniel de Araújo Viana ${ }^{1}$, Kaio Moraes de Farias ${ }^{2}$, Carlos Eduardo Bastos Lopes ${ }^{3}$, Aline Mesquita Miranda ${ }^{4}$, Ana Carolina Landim Pacheco ${ }^{5}$, Leonardo Peres Souza ${ }^{6}$, Diana Magalhães de Oliveira $^{7}$, Lúcia Daniel Machado da Silva ${ }^{8}$}

\begin{abstract}
Neoplastic disease has become an important disease in domestic dogs over the years even though in veterinary medicine there is a lack of census of neoplasms. This report describes the tumor distribution between 2003-2011 in Fortaleza (northeastern region of Brazil). A total of 1,008 samples of spontaneous tumour growths in dogs from various tumor sites were obtained. The most affected sites were skin $(52.98 \% ; n=534)$ and mammary tissue $(33.43 \% ; n=337)$. Almost no neoplasms occurred in the respiratory system $(0.10 \% ; n=1)$. The most affected breed of dogs were Poodles $(27.68 \% ; \mathrm{n}=279)$ and Crossbreeds $(19.05 \% ; \mathrm{n}=192)$, the majority of them females $(61.60 \% ; n=621)$, stricken with malignant neoplasms, comprising $53.47 \%$ of all cases $(n=539)$. The median age was 7.9 years (ranging from 3 months to 19.7 years) and most dogs were $1-8$ years $(57.54 \%$; $n=580)$ or over 8 years $(37.68 \% ; n=407)$.
\end{abstract}

Keywords: Cancer, Canine, Tumor Survey.

Resumo: A doença neoplásica tem se tornado uma importante doença em cães ao longo dos anos, apesar de que existe na medicina veterinária uma falta de censo das neoplasias. Este trabalho descreve a distribuição de tumores entre 2003-2011 em Fortaleza (região nordeste do Brasil). Um total de 1.008 amostras de tumores de crescimento espontâneo em cães, oriundos de diversos sítios tumorais, foram obtidos. Os sítios mais afetados foram a pele $(52,98 \% ; n=534)$ e tecido mamário $(33,43 \% ; n=337)$. Praticamente nenhum neoplasma ocorreu no sistema respiratório $(0,10 \% ; n=1)$. A raça mais afetada de cães foram Poodles $(27,68 \% ; n=621)$, atingidos por neoplasias malignas, compondo 53,47\% de todos os casos $(\mathrm{n}=539)$. A idade média foi de 7,9 anos (variando de 3 meses a 19,7 anos) e muitos cães possuiam de $1-8$ anos $(57,54 \% ; n=580)$ ou além de 8 anos $(37,68 \% ; n=407)$.

Palavras-Chave: Câncer, Canino, Estudo Tumoral

Autor para correspondência. E. Mail: viana.daniel78@gmail.com

Recebido 10.01.2019. Aceito em 31.03.2019

http://dx.doi.org/10.5935/1981-2965.20190003

${ }^{1}$ Professor Doutor - Faculdade de Veterinária - Universidade Estadual do Ceará - Laboratório PATHOVET Anatomia Patológica e Patologia Clínica LTDA - Fortaleza - viana.daniel78@gmail.com

${ }^{2}$ Doutorando em Biotecnologia - Universidade Federal do Ceará - Fortaleza - kaiomdf@yahoo.com.br

${ }^{3}$ Graduando em Medicina Veterinária - Faculdade de Veterinária - Universidade Estadual do Ceará - Fortaleza 1993carlos.eduardo@gmail.com

${ }^{4}$ Médica Veterinária - Especialista em Patologia Clínica Veterinária - Laboratório PATHOVET - Anatomia Patológica e Patologia Clínica Veterinária - Fortaleza - am.nena@gmail.com

${ }^{5}$ Médica Veterinária - Professora Doutora - Universidade Federal do Piauí - Picos - carolandim@ufpi.edu.br

${ }^{6}$ Biológo - Professor Doutor - Universidade Federal do Piauí - Parnaíba - leoperesouza@gmail.com

${ }^{7}$ Médica Veterinária - Professora Doutora - Universidade Estadual do Ceará - Fortaleza - diana.magalhaes@uece.br

${ }^{8}$ Médica Veterinária - Professora Doutora - Universidade Estadual do Ceará - Fortaleza -

lucia.daniel.machado@hotmail.com 


\section{Introduction}

In current literature, there is a large number of clinical information on the diagnosis and therapy of different types of neoplasia, most individually, and some information on risk factors (REIF et al., 1995; RICHARDS et al., 2001). However, there is little up-to-date information on the frequency or incidence of different types of neoplasms in the canine population anywhere in the world (DOBSON et al., 2002; BRIGHT et al., 1983). Even in the World Organization for Animal Health (OIE) these data are scarce, mostly because all animal neoplasms registries have different limitations due to different organizational structures and well-marked populations, or a wide variety in the data achieving methodology.

In veterinary medicine, the lack of census of neoplasms has, indeed, avoid the epidemiological studies when you compare to those of neoplasms in human medicine, which leads us, during the years, to an undesirable reality. After all, studies with this approach, in addition to important descriptive information, provide indications of possible variations in tumor occurrence between geographic areas (Meuten, 2017), together with information about the prevalence and distribution of individual tumors. Such data help veterinary practitioners to recognize them in time, determine an appropriate therapy, and anticipate an adequate diagnosis (VAIL \& WITHROW, 2001).

In Brazil, this kind of study is also unusual. Therefore, the purpose of our report is to describe the tumor distribution throughout some clinical aspects of neoplastic disease (age, sex, breed and tissue site), received and analyzed between 2003-2011 in Fortaleza (northeastern region of Brazil), whereas this kind of survey has only been performed regarding cutaneous neoplasms (BASTOS et al., 2017).

\section{Materials and Methods}

\section{Animals and tumors}

This study was performed over 9 years, from January 2003 to December 2011. In order to understand the tumor distribution in dogs, we performed a retrospective study within private and university veterinary pathology tumor cases. Age, gender, breed, histological type of tumor, with respective classification, and neoplasm location were recorded. A total of 1.008 samples of spontaneous tumour growths in dogs from various tumor sites were obtained. The study included dogs of all breeds and both sexes, aged between 3 months and 19.7 years, grouped in three main categories: 
animals less than 1 year, between 1-8 years and over 8 years (SOUZA et al., 2006).

\section{Histopathologic examination}

For histopathologic examination, all the tissues during the years were fixed in $10 \%$ phosphate-buffered neutral formalin, routinely processed and paraffin embedded. Tissue sections of $5 \mu \mathrm{m}$ in thickness were stained with Hematoxylin and Eosin (H\&E). Replicate sections of particular cases were also stained with special stains such as Giemsa, Periodic Acid-Schiff (PAS) and Toluidine Blue (TB) whenever it was needed to confirm the diagnosis. All tumour diagnoses were histopathologically confirmed according to WHO International Histological Classification of Tumours of Domestic Animals (GOLDSCHMIDT \& SHOFER, 1992). The criteria for histopathologic classification of investigated tumors included cellular and nuclear pleomorphism, number of nucleoli, frequency of mitosis, regularity of the cellular borders, presence of necrosis and stromal tissue.

\section{Statistical Analysis}

To stablish the relationship between some clinical and pathologic characteristics, such as gender, age, breed, broad tissue category and histopathologic type of tumor, we have performed the
Fisher's exact test. The degree of $p \leq 0.05$ was considered statistically significant.

\section{Results}

Over the past eight years a total of 1.008 samples of spontaneous tumour growths in dogs from various tumor sites were obtained. Table 01 shows the distribution of tumors throughout systems stricken by neoplasms. In our survey, the most affected systems were skin $(52.98 \%$; $\mathrm{n}=534)$ and mammary $(33.43 \% ; n=337)$. Almost no neoplasms occurred in the respiratory system $(0.10 \% ; \mathrm{n}=1)$.

Analyzing the most affected breeds of dogs we found that most dogs with neoplasms were Poodles $(27.68 \%$; $n=279)$ followed by Crossbreeds (19.05\%; $\mathrm{n}=192)$, English Cocker Spaniels (8.63\%; n=87), Yorkshire terriers $(5.25 \%, \mathrm{n}=53)$, German Shepherd Dogs and Miniature Pinschers (both with 4.16\%; $\mathrm{n}=42$ ) and Boxers (3.07\%; $\mathrm{n}=31)$. The distribution of all dog breeds in this study is represented in Table 02.

According to our records, the majority of dogs were females $(61.60 \%$; $\mathrm{n}=621$ ), stricken with malignant neoplasms comprising $53.47 \%$ of all cases $(n=539)$. The median age of the three categories of age groups was 7.9 years (ranging from 3 months to 19.7 years) and most dogs were included in the second (1- 
8 years/ 57.54\%; $\mathrm{n}=580)$ and third category (over 8 years/ $37.68 \%$; $\mathrm{n}=407$ ).

A correlation between gender, malignancy and age is represented in Table 03 and Figure 01.

The most frequent neoplasms in dogs were: mixed benign tumor $(9.32 \%$; $\mathrm{n}=94)$, mixed tumor carcinoma $(9.12 \%$; $\mathrm{n}=92)$, mammary carcinoma $(8.53 \%$; $\mathrm{n}=86)$, mammary adenoma $(6.05 \% ; \mathrm{n}=61)$, mast cell tumor $(5.55 \%$; $\mathrm{n}=56)$, squamous cell carcinoma $(4.86 \%$; $n=49)$, lymphoma (4.76\%; $\mathrm{n}=48)$, sebaceous adenoma $(3.67 \% ; n=37)$, hemangiosarcoma $(3.47 \%$; $\mathrm{n}=35)$, melanoma $(3.17 \% ; \mathrm{n}=32)$, fibrosarcoma (3.07\%; $n=31)$; histiocytoma (3.07\%; $\mathrm{n}=31)$, hemangioma $\quad(2.98 \%$; $\mathrm{n}=30)$, trichoblastoma $(2.77 \% ; \mathrm{n}=28)$, perianal gland adenoma (2.68\%; $\mathrm{n}=27)$, lipoma $(2.58 \% ; \quad n=26), \quad$ squamous papilloma $(2.58 \% ; \mathrm{n}=26)$, perianal gland carcinoma $(1.59 \% ; \mathrm{n}=16)$, leiomyoma (1.59\%; $\mathrm{n}=16)$, seminoma $(1.49 \% ; \mathrm{n}=15)$, sertoli cell tumor $(1.49 \% ; n=15)$, dermatofibroma $(1.29 \% ; \quad \mathrm{n}=13)$, plasmacytoma (1.29\%; $\mathrm{n}=13)$, fibroma (1.09\%, $\mathrm{n}=11)$, trichoepitelioma $(1.09 \%$, $\mathrm{n}=11)$ and melanocytoma $(1.09 \%, \mathrm{n}=11)$. Other tumors had a percentage below $1 \%$. Table 03 shows all tumors classified by histological type during this 9-year survey.

\section{Discussion}

In order to characterize all the neoplasms that arise spontaneously within various sites of dogs, we studied 1.008 that underwent histopathologic evaluation. The goal of this study was to describe the tumor distribution throughout some clinical aspects of neoplastic disease (age, sex, breed and tissue site). In our series, most neoplasms occurred in females $(\mathrm{p}<0.0001$ over males), with age ranging from 1-8 or over 8 years $(p<0.0001$, both significantly represented) (Figure 01). More than $50 \%$ of neoplasms diagnosed were malignant and skin tumors were more prevalent than any other kind in our survey $(52.98 \% ; n=534)$ followed by mammary neoplasms (33.43\%; $\mathrm{n}=337)$, urogenital $(7.24 \% ; \quad n=73)$ and hematopoietic $(4.86 \% ; n=49)$.

The prevalence of neoplasms, benign and malignant, is rising over the years for a variety of reasons and specially is related to animals living to increasingly older ages (MORRISON， 1998; WITHROW \& MACEWEN, 2006). The greater life span may be result of a better nutrition, vaccination programs, better preventive and therapeutic medical practices, leash laws in some countries, and possibly a deeper devotion to pet animals within the 
last 10 to 20 years (WITHROW \& MACEWEN, 2006). As a matter of fact, the human-animal bond may be the most important reason to increase animal life span, since the more concerned the owner the more attention will be paid to conditions that may cause death, (Kimura et al., 2012; Walsh, 2009) which brings us to a "bitter-sweet" reality, whereas neoplasms are older animals' disease, an increased likelihood of developing neoplasms may seem like a price to pay for living longer (WITHROW \& MACEWEN, 2006).

Our results were in accordance with those of most recent reports regarding all kinds of neoplasms (Dobson et al., 2002; Kimura et al., 2012; MacVean et al., 1978) neoplasms from a specific broad tissue category (Itoh et al., 2005; Pakhrin et al., 2007; Sforna et al., 2003; Villamil et al., 2011) or individual types of tumors (Cornell et al., 2000; Kaldrymidou et al., 2002; Ramos-Vara et al., 2000; Rogers et al., 1998) that reveal neoplasms prevalence increasing at animals in older ages. In fact, our data show approximately a $21 \%$ increase in number of cases every year and most dogs with neoplasms were between $1-8$ or over 8 years $(97.92 \%$; $\mathrm{n}=987)$.

It becomes clear that the lifetime is a predisposing condition to neoplasms development (GILSON \& PAGE, 1998; WITHROW \& MACEWEN, 2006). However, we found 21 cases of neoplasms in animals under 1 year of age $(2.08 \%$ of all neoplasms). Although this occurrence does not represent a statistically significant percentage in our cases ( $p>0.704)$, and by some authors it may be considered rare (GILSON \& PAGE, 1998; WITHROW \& MACEWEN, 2006). Attention must be paid to this particular group of animals since their tumor incidence/prevalence may increase over the years, even though slightly, as we found in our survey. For example, the youngest case registered in our data was a 3-month old German Shepherd dog bearing a subcutaneous fibrosarcoma, a tumor found mainly in much older dogs (median age 9 years) (GROSS et al., 2005). In current literature, we found a case report of a 2-month old Brazilian Fila diagnosed with osteochondroma (Sturion et al., 1997) and an important survey of 25.996 skin tumors in dogs with 652 cases from animals ranging from 2 weeks to 12-month-old (Villamil et al., 2011), two other good examples why we should keep track of neoplastic disease in youngsters.

Although the reasons for these events may not be completely clear, we can consider that the human life style that these animals are subject to at an early age 
could contribute to a premature exposure to neoplasia promoting agents, therefore, leading to a probable increase in tumor prevalence of these animals, maybe even greater than in humans. In fact, there is evidence that dogs develop neoplasms more frequently than humans (360 cases/100.000 dogs vs. 272 cases/100.000 humans) (Dorn \& Priester, 1976), in a higher prevalence in females regarding the gender of the animals (SANCHES et al., 2000).

The male/female ratio in our survey was approximately 1:2 (Figure 01), probably due to the higher prevalence of mammary tumors in females. As a matter of fact, tumors of the mammary gland comprise about $50 \%$ of all neoplasia in bitches (Daleck et al., 2005; Johnston, 1993; Morrison, 1998) and half of these are malignant (Daleck et al., 2005/ Gilbertson et al., 1983; Morrison, 1998; O' Keefe, 1997), which can contribute to the higher numbers of malignant tumor in prevalence reports, whereas the mammary tumors are always among the most predominant (DE NARDI et al., 2002; SOUZA et al., 2006; WITHROW \& MACEWEN, 2006). Our results were in accordance with these previous reports pointing out 539 cases $(53.47 \%)$ as malignant, in a 1:1 benign/malignant ratio, therefore, without statistical significance $(\mathrm{p}<0.091)$. There was, however, no breed predisposition statistically found in our data and no specific neoplasm was statistically bound to any breed, not even i.e. the mast cell tumor, mostly found in boxers (DOBSON et al., 2002; KIMURA et al., 2012).

This occurred probably because of the variety of breed distribution and different numbers of individuals composing each group of breeds.

In oncology, skin tumors are, without any doubt, the most prevalent (GOLDSCHMIDT \& SHOFER, 1992). Our series showed 534 cases $(52.98 \%)$ of skin neoplasms. This fact is frequent probably because skin conditions are easily noted by the owners leading to clinical and histopathologic examination (GROSS et al., 2005). One of the first standardized report on tumor occurrence was performed between 1963 and 1967 reporting 1.077 skin tumor cases in dogs to every 100.000 animals/year (DORN et al., 1968a; DORN et al., 1968b). In another survey, the skin tumor incidence was 1.126/100.000 animals/year (MacVean et al., 1978).

Goorman \& Dobson stablished that cutaneous neoplasms were more diagnosed when compared to other tumor sites and accounted for approximately $30 \%$ of all neoplastic 
disease in dogs, which does not agree to our results since we found more than $50 \%$ of skin tumors. Another report showed that $1 / 3$ of all neoplasms in dogs are cutaneous neoplasms (Vail \& Withrow, 2007) comprising mast cell tumors, perianal gland adenomas, lipomas, sebaceous gland adenoma, fibrosarcoma, melanoma, histiocytoma, squamous cell carcinomas, hemangiopericytoma and basal cell carcinoma.

In Brazil, this kind of study is unusual. However, most recent national researches (Kimura et al., 2012; Sanches et al., 2000) detected a high incidence of skin tumors, followed by mammary and urogenital neoplasms, as we also found in our series of data.

Various different types of tumors were diagnosed during our 9-year survey and Table 03 presents a detailed distribution of all neoplams diagnosed in our report, displaying broad tissue category, malignancy and total number of cases, with respective percentage. The most frequent neoplasms in dogs were: mixed benign tumor $(9.32 \%$; $=94)$, mixed tumor carcinoma $(9.12 \% ; \quad n=92)$, mammary carcinoma $(8.53 \% ; n=86)$, mammary adenoma (6.05\%; $n=61)$, mast cell tumor $(5.55 \% ; n=56)$, squamous cell carcinoma $(4.86 \% ; \mathrm{n}=49)$, lymphoma (4.76\%; n=48). Although individually the first four categories belong to tumors in mammary gland, skin tumors were more prevalent in our survey as pointed out before. According to Table 03 there was 534 cutaneous neoplasms comprising mainly 56 mast cell tumors (5.55\%), 49 squamous cell carcinomas $(4.86 \%)$ and 37 sebaceous adenomas (3.67\%). Such data are in accordance with other surveys (Conroy, 1983; Strafuss, 1976; Strafuss et al., 1976; Trein, 1965), that also stablished a higher prevalence of malignant neoplasms in cutaneous tissue.

Except for skin cancers whose incidence is the highest in all animal species, most studies on canine neoplasms report the supremacy of mammary tumors in dogs, constituting about $25 \%$ of all cancers (BOSTOCK \& OWEN, 1975; JUBB \& KENNEDY, 1985; MOULTON, 1990). According to this idea, in this study we found a high frequency of mammary tumors (337), with the prevalence of mixed benign tumor $(9.32 \%$; $n=94)$, mixed tumor carcinoma $(9.12 \% ; n=92)$, mammary carcinoma $(8.53 \% ; \mathrm{n}=86)$, mammary adenoma $(6.05 \% ; n=61)$. The high rate of mixed tumor diagnosed was also recorded by other authors (BRODEY et al., 1983; MISDORP et al., 1973; TREIN, 1965).

Genitourinary tumors were the third most frequent type of neoplasia in 
our report accounting for 73 cases $(7.24 \%)$ comprising 16 (1.59\%) leiomyomas, 15 $(1.49 \%)$ seminomas, $15(1.49 \%)$ Sertoli cell tumors, $9(0.89 \%)$ transmissible venereal tumors. All the others tumors were distributed throughout various sites. Figure 02 represents photomicrographs of most prevalent tumors in dogs.

\section{Conclusions}

It was found in the present study that a considerable amount of the described cases was involved exclusively with skin tumors, together with the mammary neoplasms among females. Some environmental factors may be associated with this prevalence. Therefore, more local epidemiological studies are necessary to fulfill the gaps that remain unknown in the small animal clinical practice, making it possible for us to better understand and prevent illnesses.

\section{References}

1. BASTOS, R.S.C.; FARIAS, K.M.; LOPES, C.E.B.; PACHECO, A.C.L.; VIANA, D.A. Estudo retrospectivo de neoplasias cutâneas em cães da região metropolitana de Fortaleza. Revista Brasileira de Higiene e Sanidade Animal. v.11, n.1, p.39-53, 2017.

2. BOSTOCK, D.E.; OWEN, L.N. Neoplasia in the cat, dog and horse. Wolfe Publishing Ltd., London, 1975. 144p.
3. BRIGHT, R.M.; GORMAN, N.T.; PROBST, C.W.; GORING, R.L. Transmissible venereal tumor of the soft palate in dog. Journal of the American Veterinary Medical Association, Washington, v. 183 , v. 8 , p. 893-895, 1983.

3. BRODEY, R.S.; GOLDSCHMIDT, M.H.; ROSZEL, J.R. Canine mammary gland neoplasms. Journal of the American Animal Hospital. v.19, p.61-90, 1983.

4. CORNELL, K.K.;BOSTWICK, D.G.; COOLEY, D.M.; HALL, G.; HARVEY, H.J.; HENDRICK, M.J.; PAULI, B.U.; RENDER, J.A.; STOICA, G.; SWEET, D.C.; WATERS, D.J. Clinical and Pathologic Aspects of Spontaneous Canine Prostate Carcinoma: A Retrospective Analysis of 76 Cases. The Prostate. v.45, p.173-183, 2000.

5. CONROY, J.D. Canine skin tumors. Journal of the American Animal Hospital. v.19, p.91-114, 1983.

6. DALECK, C.R.; COSTA NETO, J.M.; ALESSI, A.C. Prótese traqueal em cães com traquéia homóloga. Estudo experimental. Veterinária Notícias. v.4, n.1, p.57-62, 1998.

7. DE NARDI, A.B.; RODASKI, S.; SOUSA, R.S.;COSTA, T.A.;MACEDO, T.R.; RODIGHERI, S.M.; RIOS, A.;PIEKARZ, C.H. Prevalência de Neoplasias e Modalidades de Tratamentos em Cães atendidos no Hospital Veterinário da Universidade Federal do Paraná. Archives of Veterinary Science. v.7, n.2, p.15-26, 2002. 
8. DOBSON, J.M.; SAMUEL, S.; MILSTEIN, H.; ROGERS, K.;WOOD, J.L. Canine neoplasia in the UK: estimates of incidence rates from a population on insured dogs. Journal of Small Animal Practice.; v.43, p.240-246, 2002.

9. DORN, C.R.;PRIESTER, W.A. Epidemiologic analysis of oral and pharyngeal cancer in dogs, cats, horses, and cattle. Journal of the American Veterinary Medical Association. v.169, p.1202-1206, 1976.

10. DORN, C.R.; AYLOR D.O.N.;FRYE, F.L.; HIBBARD, H.H. Survey of animal neoplasms in Alameda and Contra Costa Counties, California. I. Methodology and description of cases. Journal of the National Cancer Institute. v.40, p.295-305, 1968a.

11. DORN, C.R.;TAYLOR, D.O.N.; SCHNEIDER, R.;HIBBARD, H.H.; KLAUBER, M.R. Survey of animal neoplasms in Alameda and Contra Costa Counties, California. II. Cancer morbidity in dogs and cats from Alameda County. Journal of the National Cancer Institute. v.40, p.307-318, 1968 b.

12. GILBERTSON, S.R.;KURZMAN, I.D.; ZACHRAU, R.E.; HURVITZ, A.I.;BLACK, M.M. Canine mammary epithelial neoplasms: biologic implications of morphologic characteristics assessed in 232 dogs. Veterinary Pathology. v.20, p.127-142, 1983.

13. GILSON, S.D.; PAGE, R.L. Princípios de oncologia. In: BIRCHARD, S.J.; SHERDING, R. G. Manual Saunders: Clinica de pequenos animais. São Paulo: Roca, 1998, p.09-217.
14. GOLDSCHMIDT, M.H.;SHOFER, F.S. Skin tumors of the dog and cat. Oxford: Pergamon, 1992, 316p.

15. GOORMAN, N.T.;DOBSON, J.M. The skin and associated tissues. In: WHITE, R.A.S. Manual of small animal oncology. Gloucester: British Small Animal Veterinary Association, 1995. p.187-200.

16. GROSS, T.L.;IHRKE, P.J.;WALDER, E.J. VERENA, K.A. Skin diseases of the dog and cat: Clinical and histopathologic diagnosis. Oxford: Blackwell Science, 2005, 932p.

17. ITOH, T.; UCHIDA, K.; ISHIKAWA, K.; KUSHIMA, K.;KUSHIMA, E.;TAMADA, H.; MORITAKE, T.;NAKAO, H.;SHII, H. Clinicopathological survey of 101 canine mammary gland tumors. Journal of Veterinary Medical Science. v.67, p.345347, 2005.

18. JOHNSTON, S.D.; Reproductive systems. In: SLATTER, D.H. Textbook of small animal surgery. 2.ed. Philadelphia: Saunders, 1993, p.2177-2199.

19. JUBB, K.V.F.;KENNEDY, P.C. Pathology of domestic animals. 3th ed. Toronto: Academic Press, 1985(2), 582p.

\section{KALDRYMIDOU, H.;LEONTIDES, L.; KOUTINAS,} A.F.;SARIDOMICHELAKIS, M.N.; KARAYANNOPOULOU, M. Prevalence, distribution and factors associated with the presence and the potential for malignancy of cutaneous neoplasms in 174 dogs admitted to a clinic in Northern Greece. 
Journal of the American Veterinary Medical Association. v.49, p.87-91, 2002.

21. KIMURA, K.C.; GÁRATE, A.P.; DAGLI, M.L.Z. Retrospective study of Neoplasms in Domestic Animals: A Survey Between 1993 and 2002 of the Service of Animal Pathology, Department of Pathology, School of Veterinary Medicine and Animal Science, University of Sao Paulo, Southeast Brazil. Brazilian Journal of Veterinary Pathology. v.5, n.2, p.60-69, 2012.

22. MACVEAN, D.W.;MONLUX, A.W.; ANDERSON, P.S.; SILBERG, S.L.; ROSZEL, J.F. Frequency of Canine and Feline Tumors in a defined population. Veterinary Pathology. v.15, n.6, p.700$715,1978$.

23. MEUTEN, D.J. Tumors in Domestic Animals. 5.ed. Ames, Iowa: John Wiley \& Sons Inc, 2017, 979p.

24. MISDORP, W.; COTCHIN, E.; HAMPE, J.F.; JABARA, A.G.; VON SANDERSLEBEN, J. Canine malignant mammary tumors, III. Special types of carcinomas malignant mixed tumors. Veterinary Pathology. v.10, p.241-256, 1973.

25. MORRISON, W.B. Canine and feline mammary tumors. In: MORRISSON, W.B. Cancer in dogs and cats. Medical and surgical treatment. Baltimore: Willians \& Wilkins, 1998. ch. 39, p.591598.
26. MOULTON, J.E. Tumors of the mammary gland. In: MOULTON, J.E. Tumors in domestic animals. 3.ed. University of California, 1990. p.519-550.

27. PAKHRIN, B.;KANG, M.;BAE, I.; PARK, M.;JEE, H.;YOU, M.;KIM, J.; YOON, B.; CHOI, Y.; KIM, D. Retrospective study of canine cutaneous tumors in Korea. Journal of Veterinary Science v.8, n.3, p.229-236, 2007.

28. O' KEEFE, D.A. Tumores do sistema genital e das glândulas mamárias. In: ETTINGER, S.J.; FELDMAN, E.C. Tratado de Medicina Interna Veterinária. 4.ed. São Paulo: Manole, 1997. p.23442354.

29. RAMOS-VARA, J.A.; BEISSENHERZ, M.E.; MILLER, M.A.; JOHNSON, G.C.; PACE, L.W.; FARD, A.; KOTTLER, S.J. Retrospective Study of 338 Canine Oral Melanomas with Clinical, Histologic, and Immunohistochemical Review of 129 Cases. Veterinary Pathology. v.37, n.6, p.597-608, 2000.

30. REIF, J.S.;LOWER, K.S.;OGILVIE, G.K. Residential exposure to magnetic fields and risk of canine lymphoma. American Journal of Epidemiology. v.14, n.1, p.352-359, 1995.

31. RICHARDS, H.G.;MCNEIL, P.E.; THOMPSON, H.;REID, S.W.J. An epidemiological analysis of a canine biopsies database compiled by a diagnostic histopathology service. Society for Veterinary Epidemiology and Preventive Veterinary Medicine. v. 51, p.125-136, 2001. 
32. ROGERS, K.S.;WALKER, M.A.; DILLON, H.B. Transmissible venereal tumor: A retrospective study of 29 cases. American Animal Hospital Association. v.34, p.463-470, 1998.

33. SANCHES, R.C.;REGONATO, E.; ZILIOTTO, L.; VICENTI, F.A.M.; DALECK, C.R. Doenças neoplásicas em cães: estudo retrospectivo de 535 casos. In: CONGRESSO BRASILEIRO DE CIRURGIA E ANESTESIOLOGIA VETERINÁRIA, 2000. Goiânia. Anais... Editora da Universidade Federal do Goiás, 2000. p.42.

34. SFORNA, M.;BRACHELENTE, C.; LEPRI, E.; MECHELLI, L. Canine ovarian tumours: a retrospective study of 49 cases. Veterinary Research Communications. v.27, p.359-361, 2003.

35. SOUZA, T.M.;FIGUERA, R.A.; IRIGOYEN, L.F.;BARROS, C.S.L. Estudo retrospectivo de 761 tumores cutâneos em cães. Ciência Rural. v.36, n.2, p.555-560, 2006.

36. STRAFUSS, A.C. Basal cell tumors in dogs. Journal of the American Veterinary Medical Association. v.169, n.3, p.322324, 1976.

37. STRAFUSS, A.C.; COOK, J.E.; SMITH, J.E. Squamous cells carcinoma in dogs. Journal of the American Veterinary Medical Association. v.168, n.5, p.425427, 1976.

38. STURION，D.J.;SANTOS， P.C.G.; SANTOS, R.V.;LAGANARO, S.L.; ABREU, C.B.;ISQUERDO, R.;GARBELINI, M.E. Osteocrondoma em cão Fila Brasileiro. In: PEREZ AD, RUTTEMAN GR, PENA L. CONGRESSO BRASILEIRO DE CLÍNICOS VETERINÁRIOS DE PEQUENOS ANIMAIS, 1997. Curitiba. Anais... Curitiba: Associação Nacional de Clínicos Veterinários - Paraná, 1997. p.48.

39. TREIN, E.J. Contribuição ao estudo da incidência de processos neoplásicos nos caninos domésticos. Revista da Faculdade de Agronomia e Veterinária. v.7, n.1, p.510, 1965.

40. VAIL, D.M.;WITHROW, S.J. Tumors of the skin and subcutaneous tissues. In: WITHROW, S.J.; MACEWEN, E.G. Small animal clinical oncology. 4.ed. Philadelphia: W. B. Saunders, 2007. ch.18, p.375-401.

41. VAIL, D.M.;WITHROW, S.J. Tumors of the skin and subcutaneous tissues. In: WITHROW, S.J.;MACEWEN, E.G. Small animal clinical oncology. 3.ed. Philadelphia: Saunders Company, 2001. p.233-260.

42. VILLAMIL, J.A.; HENRY, C.J.; BRYAN, J.N.; ELLERSIECK, M.;TYLER, J.W.; HAHN, A.W. Identification of the most common cutaneous neoplasms in dogs and evaluation of breed and age distributions for selected neoplasms. Journal of the American Veterinary Medical Association. v.239, n.7, p.960-965, 2011.

43. WALSH, F. Human-animal bonds I: the relational significance of companion animals. Fam Process. v.48, n.4, p.462480, 2009. 
Viana et al., Revista Brasileira de Higiene e Sanidade Animal (v.13, n.1) p. 48 - 67 jan - mar (2019)

MACEWEN, E.G. Small Animal

44. WITHROW, S.J.; MACEWEN, E.G. Oncology, 2.ed. W. B. Saunders, Soft tissue sarcomas. In: WITHROW, S.J.; $\quad$ Philadelphia, PA, 1996. p.211-226. 
Viana et al., Revista Brasileira de Higiene e Sanidade Animal (v.13, n.1) p. 48 - 67 jan - mar (2019)

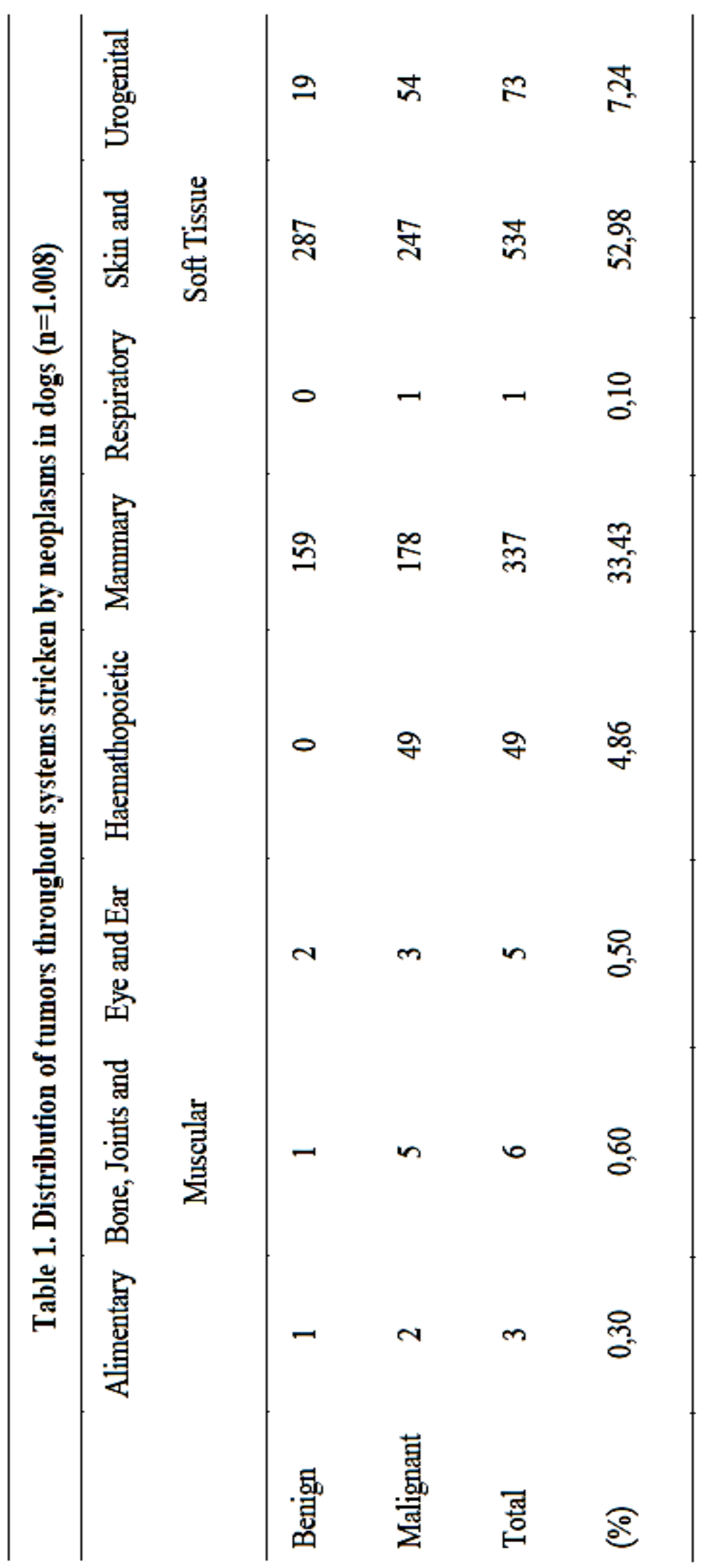


Viana et al., Revista Brasileira de Higiene e Sanidade Animal (v.13, n.1) p. 48 - 67 jan - mar (2019)

Table 02. Major breeds of dogs affected with tumors (total number and percentage) $(\mathbf{n}=\mathbf{1 . 0 0 8})$.

Breed Number of

Animals

\begin{tabular}{|c|c|c|}
\hline Airedale Terrier & 1 & 0.09 \\
\hline Akita Inu & 6 & 0.59 \\
\hline Argentine Dogo & 3 & 0.29 \\
\hline American Pitbull Terrier & 30 & 2.98 \\
\hline Basset Hound & 8 & 0.79 \\
\hline Beagle & 12 & 1.19 \\
\hline Belgian Shepherd Dog & 5 & 0.49 \\
\hline Bichon Frisé & 3 & 0.29 \\
\hline Boxer & 31 & 3.07 \\
\hline Brazilian Terrier & 5 & 0.49 \\
\hline Brittany & 3 & 0.29 \\
\hline Chow Chow & 2 & 0.19 \\
\hline Collie & 2 & 0.19 \\
\hline Crossbreeds & 192 & 19.05 \\
\hline Dachshund & 30 & 2.98 \\
\hline Dalmatian & 9 & 0.89 \\
\hline Dobermann Pinscher & 7 & 0.69 \\
\hline Dogue de Bordeaux & 2 & 0.19 \\
\hline English Bulldog & 4 & 0.40 \\
\hline English Cocker spaniel & 87 & 8.63 \\
\hline English Pointer & 6 & 0.59 \\
\hline Fila Brasileiro & 9 & 0.89 \\
\hline French Bulldog & 3 & 0.29 \\
\hline German Shepherd Dog & 42 & 4.16 \\
\hline Golden Retriever & 1 & 0.09 \\
\hline
\end{tabular}


Viana et al., Revista Brasileira de Higiene e Sanidade Animal (v.13, n.1) p. 48 - 67 jan - mar (2019)

\begin{tabular}{|c|c|c|}
\hline Great Dane & 10 & 0.99 \\
\hline Labrador Retriever & 17 & 1.69 \\
\hline Lhasa Apso & 4 & 0.40 \\
\hline Maltese & 14 & 1.39 \\
\hline Miniature Pinscher & 42 & 4.16 \\
\hline Neapolitan Mastiff & 3 & 0.29 \\
\hline Old English Sheepdog & 1 & 0.09 \\
\hline Pekingese & 8 & 0.79 \\
\hline Poodle & 279 & 27.68 \\
\hline Pug & 2 & 0.19 \\
\hline Rottweiler & 27 & 2.68 \\
\hline Schnauzer & 14 & 1.39 \\
\hline Scottish Terrier & 3 & 0.29 \\
\hline Shar pei & 2 & 0.19 \\
\hline Shetland Sheepdog & 1 & 0.09 \\
\hline Shih Tzu & 6 & 0.59 \\
\hline Siberian Husky & 7 & 0.69 \\
\hline Weimaraner & 7 & 0.69 \\
\hline $\begin{array}{l}\text { West Highland White } \\
\text { Terrier }\end{array}$ & 3 & 0.29 \\
\hline Whippet & 1 & 0.09 \\
\hline Yorkshire Terrier & 53 & 5.25 \\
\hline
\end{tabular}


Viana et al., Revista Brasileira de Higiene e Sanidade Animal (v.13, n.1) p. 48 - 67 jan - mar (2019)

Table 03 - Classification of tumors by histological type (total number and percentage) $(\mathbf{n}=1.008)$.

\begin{tabular}{|c|c|c|c|c|}
\hline $\begin{array}{l}\text { Broad Tissue } \\
\text { category }\end{array}$ & Malignancy & Tumors & $\begin{array}{l}\text { Number } \\
\text { of Cases }\end{array}$ & $\%$ \\
\hline \multirow[t]{2}{*}{ Alimentary } & Benign & Pleomorphic adenoma of the salivary gland & 1 & 0.10 \\
\hline & Malignant & Intestinal acinar adenocarcinoma & 2 & 0.20 \\
\hline \multirow{3}{*}{$\begin{array}{l}\text { Bone, Joints and } \\
\text { Muscular }\end{array}$} & Benign & Osteochondroma & 1 & 0.10 \\
\hline & Malignant & Condrosarcoma & 1 & 0.10 \\
\hline & & Osteosarcoma & 4 & 0.40 \\
\hline \multirow[t]{3}{*}{ Eye and Ear } & Benign & Ceruminous gland adenoma & 2 & 0.20 \\
\hline & & Meibomian gland adenoma & 1 & 0.10 \\
\hline & Malignant & Ceruminous gland carcinoma & 3 & 0.30 \\
\hline \multirow[t]{2}{*}{ Haematopoietic } & Malignant & Lymphoma (lymphosarcoma) & 48 & 4.76 \\
\hline & & Leukaemia & 1 & 0.10 \\
\hline \multirow[t]{6}{*}{ Mammary } & Benign & Adenoma & 61 & 6.05 \\
\hline & & Ductal papilloma & 3 & 0.30 \\
\hline & & Fibroadenoma & 1 & 0.10 \\
\hline & & Mixed benign tumor & 94 & 9.32 \\
\hline & Malignant & Carcinoma & 86 & 8.53 \\
\hline & & Mixed tumor carcinoma & 92 & 9.12 \\
\hline Respiratory & Malignant & Acinar adenocarcinoma of the lung & 1 & 0.10 \\
\hline Skin and soft tissue & Benign & Apocrine adenoma & 1 & 0.10 \\
\hline
\end{tabular}


Viana et al., Revista Brasileira de Higiene e Sanidade Animal (v.13, n.1) p. 48 - 67 jan - mar (2019)

\begin{tabular}{|c|c|c|c|}
\hline & Apocrine cystadenoma (hidrocystoma) & 1 & 0.10 \\
\hline & Apocrine ductular adenoma (hidradenoma) & 1 & 0.10 \\
\hline & Dermatofibroma & 13 & 1.29 \\
\hline & Fibroma & 11 & 1.09 \\
\hline & Hemangioma & 30 & 2.98 \\
\hline & Histiocytoma & 31 & 3.07 \\
\hline & Infundibular keratinizing acanthoma & 5 & 0.50 \\
\hline & Lipoma & 26 & 2.58 \\
\hline & Melanocytoma & 11 & 1.09 \\
\hline & Perianal gland adenoma & 27 & 2.68 \\
\hline & Pilomatricoma & 5 & 0.50 \\
\hline & Plasmacytoma & 13 & 1.29 \\
\hline & Sebaceous adenoma & 37 & 3.67 \\
\hline & Sebaceous epithelioma & 6 & 0.59 \\
\hline & Squamous papilloma & 26 & 2.58 \\
\hline & Trichoblastoma & 28 & 2.77 \\
\hline & Trichoepithelioma & 11 & 1.09 \\
\hline & Trichofolliculoma & 1 & 0.10 \\
\hline Malignant & Apocrine carcinoma & 6 & 0.50 \\
\hline & Basal cell carcinoma & 9 & 0.89 \\
\hline
\end{tabular}


Viana et al., Revista Brasileira de Higiene e Sanidade Animal (v.13, n.1) p. 48 - 67 jan - mar (2019)

\begin{tabular}{|c|c|c|c|c|}
\hline & & Basosquamous carcinoma & 2 & 0.20 \\
\hline & & Fibrosarcoma & 31 & 3.07 \\
\hline & & Hemangiosarcoma & 35 & 3.47 \\
\hline & & Liposarcoma & 2 & 0.20 \\
\hline & & Malignant fibrous histiocytoma & 5 & 0.50 \\
\hline & & Mast cell tumor & 56 & 5.55 \\
\hline & & Melanoma & 32 & 3.17 \\
\hline & & Myxosarcoma & 1 & 0.10 \\
\hline & & Perianal gland carcinoma & 16 & 1.59 \\
\hline & & Sebaceous carcinoma & 5 & 0.50 \\
\hline & & Squamous cell carcinoma & 49 & 4.86 \\
\hline Urogenital & Benign & Leiomyoma & 16 & 1.59 \\
\hline & & Granulosa cell tumor & 1 & 0.10 \\
\hline & & Teratoma & 1 & 0.10 \\
\hline & & Urothelial papilloma & 1 & 0.10 \\
\hline & Malignant & Disgerminoma & 2 & 0.20 \\
\hline & & Leiomyosarcoma & 1 & 0.10 \\
\hline & & Leydigocitoma & 5 & 0.50 \\
\hline & & Renal cell carcinoma & 2 & 0.20 \\
\hline & & Renal tubular carcinoma & 1 & 0.10 \\
\hline & & Seminoma & 15 & 1.49 \\
\hline
\end{tabular}


Viana et al., Revista Brasileira de Higiene e Sanidade Animal (v.13, n.1) p. 48 - 67 jan - mar (2019)

Sertoli cell tumor

Transitional cell carcinoma

Transmissible venereal tumor

Wilms tumor (nephroblastoma)
15

$3 \quad 0.30$

9

0.89

$1 \quad 0.10$

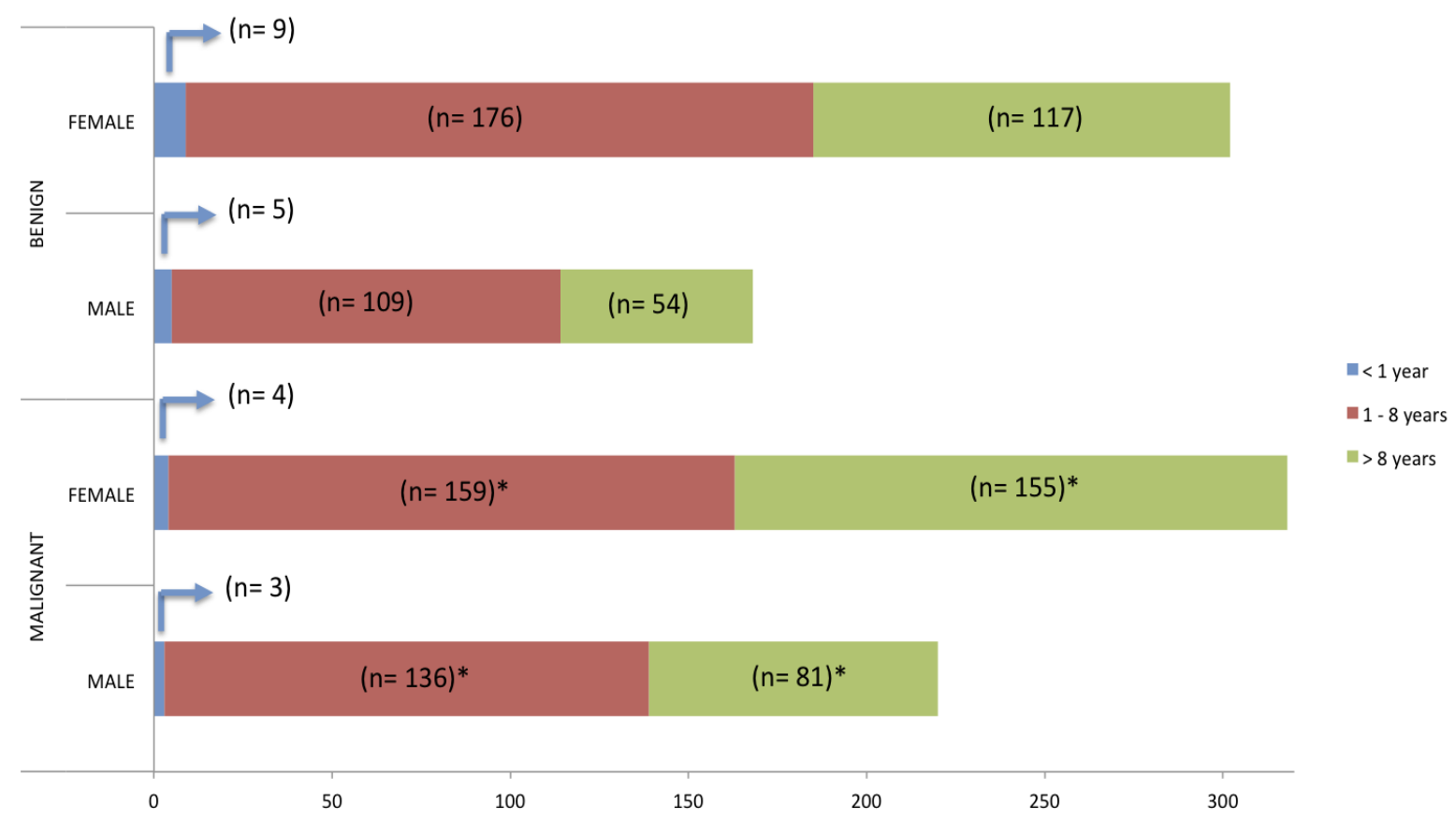

Figure 01 - Distribution of neoplastic cases in dog related to gender (male/female), malignancy (benign/malignant) and age $(<1$ year/1-8 years/ $>8$ years) $(n=1.008)$. The $(*)$ represents statistical significance through the groups. 


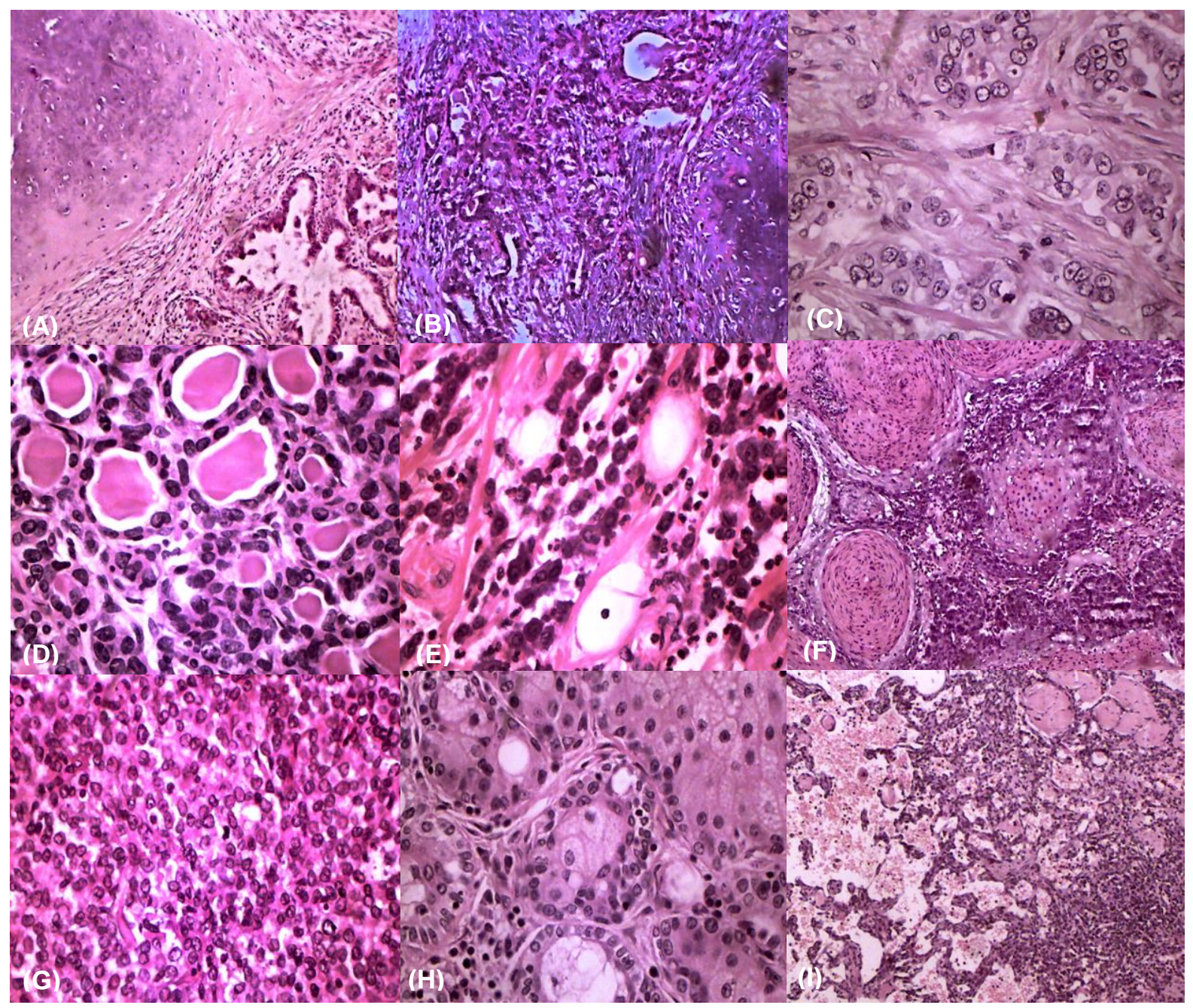

Figure 02 - Photomicrographs of most prevalent tumors in dogs stained with H\&E. (A) Benign Mixed Tumor, mammary gland, canine. Both epithelial and chondroid elements are benign interspersed with a cellular stroma. 40x. (B) Mixed Tumor Carcinoma, mammary gland, canine. The chondroid component is benign, but there is moderate nuclear pleomorphism of the ductal epithelial cells. 40x. (C) Carcinoma, mammary gland, canine. Moderate nuclear pleomorphism of the ductal epithelial cells with stroma invasion. 200x. (D) Adenoma, mammary gland, canine. The ducts are lined by a uniform population of columnar epithelial cells and myoepithelial cells. Small amount of stroma interspersed. 200x. (E) Mast Cell Tumor, skin, canine. Sheets of neoplastic mast cells. Aggregates of eosinophils are also present. 200x. (F) Squamous Cell Carcinoma, skin, canine. Islands and trabeculae of squamous malignant cells with central accumulations of compact laminated keratin or parakeratotic cells throughout the adjacent connective tissue. 40x. (G) Lymphoma, lymph node, canine. Solid sheets of malignant lymphocytes with monomorphic appearance. 200x. (H) Sebaceous Adenoma, skin, canine. Lobules of sebaceous cells showing normal maturation from the basaloid peripheral reserve cell layer to large, pale, lipid-laden central cells (sebocytes). 200x. (I) Hemangiosarcoma, skin, canine. Endothelial malignant cells forming an anastomosing meshwork of blood-filled channels of varying size and sometimes solid areas. 40x. 